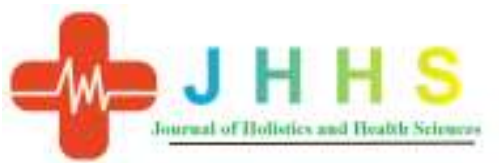

\title{
Efektivitas Pelatihan Pembuatan PMT Menu Lokal Terhadap Pengetahuan Dan Sikap Ibu Dalam Memberikan Pmt Pada Balita Dengan Gizi Kurang Di Desa Leyangan
}

\author{
G.A.KD Ratna Kusumasari ${ }^{1}$, Wahyu Kristiningrum ${ }^{2}$, Luvi Dian Afriyani ${ }^{3}$ \\ ${ }^{1,2,3}$ Fakultas Ilmu Kesehatan Program Studi D IV Kebidanan Universitas Ngudi \\ Waluyo \\ E-mail : gusayuleo@gmail.com
}

\begin{abstract}
ABSTRAK
Jumlah penderita gizi kurang di dunia mencapai 104 juta anak dan keadaan gizi kurang masih menjadi penyebab sepertiga kematian anak di seluruh dunia.Upaya penanganan masalah gizi kurang harus mendapatkan tatalaksana perawatan yang sesuai sehingga diperlukan pelatihan pembuatan PMT menu lokal untuk meningkatkan pengetahuan dan sikap ibu dalam memberikan PMT menu lokal pada balita gizi kurang agar meningkatkan status gizi balita yang baik. Penelitian ini bertujuan untuk mengetahui efektivitas pelatihan pembuaatan PMT menu lokal terhadap pengetahuan dan sikap ibu dalam memberikan pmt pada balita dengan gizi kurang di Desa Leyangan jenis penelitian yang digunakan adalah quassy eksperiment dengan rancangan one group pretest dan posttest design. Pengambilan sampel menggunakan proportuionate random sampling. Jumlah sampel pada penelitian ini sebanyak 20 responden dan analisis menggunakan analisa univariat dan bivariat. Dari hasil penelitian didapatkan tingkat pengetahuan sesudah diberikan pelatihan PMT menu lokal pada kategori baik sebanyak 18 responden (90,0\%), kategori cukup sebanyak 2 responden (10,0\%). Pada sikap responden sesudah diberikan pelatihan PMT menu lokal sikap ibu dengan kategori positif sebanyak 19 responden $(95,0 \%)$ dan kategori sikap negatif sebanyak 1 responden $(5,0 \%)$. Berdasarkan hasil penelitian bahwa pelatihan pembuatan PMT menu lokal efektif digunakan untuk meningkatkan pengetahuan dan sikap ibu dalam memberikan PMT pada balita dengan gizi kurang di Desa Leyangan dengan nilai $p$-value 0,000 .
\end{abstract}

\section{Kata Kunci : Pengetahuan, Sikap, Pelatihan pembuatan PMT menu lokal}

\section{ABSTRACT}

The Effectiveness Of PMT-Making Training with Local Menu on Mother's Knowledge and Behavior in Giving PMT to Malnourished Toddlens at Leyangan Vilage

The number of malnourished people in the world reaches 104 million children and the condition of malnutrition is still the cause of one third of all causes of child mortality in the world. This has not received attention so that it is required training for creating PMT with local menus to improve the knowledge and

Efektivitas Pelatihan Pembuatan ... G.A.KD Ratna Kusumasari, Wahyu Kristiningrum, Luvi Dian Afriyani 
attitudes of mothers in giving PMT with local menus to malnustrihed toddles in order to improve the children nutritional status. This research aims to determine the effectiveness training of PMT making local menus on knowledge and attitude of mother in giving PMT to toddlers with malnutrition in Leyangan Village. The type of research quassy experiment with the design of one group pretest and posttest design. The sampling technive was proportuionate random sampling. The number of samples in this study were 20 respondents and the analysis used was univariate and bivariate analysis. From the result training the knowledge level after given training was on "good" level with 18 respondent (90\%), "adequate" level with 2 respondent (20\%). The attitude after given the training was 19 respondent (95\%) with in "positif" catesony and 1 responden (5\%) with in "negative" catesony. Based on the results of the research, the training in making local menu PMT is effective to increase the knowledge and attitudes of mothers in giving PMT to toddlers with malnutrition at Leyangan Village with p-value $p$ 0,000 .

\section{Keywords: Knowledge, Attitude, Training manufacture Local PMT menu}

\section{PENDAHULUAN}

Menurut WHO (2012), mengatakan bahwa jumlah penderita gizi kurang di dunia mencapai 104 juta anak dan keadaan gizi kurang masih menjadi penyebab sepertiga dari seluruh penyebab kematian anak di seluruh dunia. Asia selatan merupakan wilayah denganprevalensi gizi kurang terbesar di dunia, yaitu sebesar $46 \%$ kemudian wilayah sub-Sahara Afrika $28 \%$, Amerika Latin $7 \%$ dan yang paling rendah terdapat di Eropa Tengah, Timur, dan Commonwealthn of IndependentStates (CEE/CIS) sebesar $5 \%$. UNICEF melaporkan sebanyak 167 juta anak usia prasekolah di dunia yang menderita gizi kurang (Maisarah, 2016).

Upaya penanganan masalah gizi kurang hingga saat ini masih terfokus pada penderita gizi buruk, sementara penderita gizi kurang belum cukup mendapat perhatian. Kurangnya intervensi gizi bagi penderita gizi kurang dapat memunculkan persoalan kesehatan masyarakat yang lebih serius karena penderita gizi kurang sangat mudah terjatuh ke dalam kondisi gizi buruk. Oleh karena itu, anak yang megalami keadaan kurang gizi memerlukan makanan yang bermutu dari segi gizi baik kuantitas maupun kualitas secara terus-menerus. Pemantauan Status Gizi (PSG) tahun 2017 bahwa persentase gizi buruk pada balita usia 0-59 bulan di Indonesia adalah 3,8\%, sedangkan persentase gizi kurang persentase gizi kurang adalah 14 . Hal tersebut tidak berbeda jauh dengan hasil PSG tahun 2016 yaitu persentase gizi buruk pada balita usia 0-59 bulan sebesar sebesar 3,4\% dan presentase gizi kurang sebesar 14,43\% (Kementrian Kesehatan RI, 2017).

Usaha yang dapat dilakukan untuk menanggulangi masalah ini adalah dengan pemberian makanan tambahan. Kementerian kesehatan telah menetapkan kebijakan yang komprehensif, meliputi pencegahan, promosi/edukasi dan penanggulangan balita gizi buruk. Upaya pencegahan dilaksanakan melalui pemantauan pertumbuhan di 
posyandu. Penanggulangan balita gizi kurang dilakukan dengan pemberian makanan tambahan (PMT). Untuk meningkatkan kandungan gizi, bahan-bahan tersebut dapat disubstitusi dengan bahan pangan lokal sumber protein dan vitamin A. Salah satu bahan pangan lokal yang bernilai gizi tinggi yang dapat dimanfaatkan sebagai bahan makanan tambahan yang mudah dijangkau masyarakat adalah bola tempe saus kuning merupakan salah satu pangan lokal yang memiliki kandungan gizi yang beragam seperti protein 10 gram, dan energy $250 \quad$ Kkal per porsinya(Iskandar, 2017).

$$
\text { Menurut Penelitian }
$$

Katmawanti (2018), mengatakan bahwa metode pelatihan dengan demonstrasi dan praktik memberikan keefektivitasan yang bermakna terhadap peningkatan pengetahuan. Pelatihan Pembuatan PMT Modisco dengan metode ini memberikan kesan yang mendalam pada peserta. Peserta juga dilibatkan dalam kegiatan yaitu praktik. Hal ini sejalan dengan penelitian yang dilakukan oleh (Rapiasih, dkk, 2010) menyimpulkan bahwa ada peningkatan pengetahuan sesudah diadakan pelatihan Pembuatan PMT Modisco dengan presentase sebelum $14,12 \%$ dan sesudah $71,00 \%$ peningkaatan sebesar $56,88 \%$ (Katmawanti dkk, 2018).

Hasil studi pendahuluan yang telah peneliti lakukan pada ibu yang memiliki balita gizi kurang di wilayah puskesmas leyangan, peneliti mendapatkan data di puskesmas leyangan dengan jumlah balita gizi kurang sebanyak 152 balita pada tahun 2018. Wilayah kerja puskesamas ini meliputi wilayah Leyangan, Kalirejo,
Gedanganak, Sidomulyo, dan Beji. Dari data Puskesmas Leyangan pada tahun 2018 jumlah gizi kurang di wilayah Leyangan sebanyak 55 balita, wilayah Gedanganak sebanyak 37 balita, wilayah Kalirejo sebanyak 18 balita, wilayah Sidomulyo sebanyak 7 balita dan wilayah Beji sebanyak 35 balita. Dari 13 ibu yang memiliki balita gizi kurang yang di tes dengan beberapa pertanyaan tentang PMT, dimana 10 ibu belum mengerti yang dimaksud dengan PMT, 7 ibu mengatakan belum pernah diberikan pendidikan kesehatan tentang cara membuat makanan tambahan, ibu juga belum menerapkan memberikan makanan tambahan dirumah, makanan tambahan yang diberikan setiap 1 bulan sekali diposyandu hanya berupa kacang hijau dan biscuit terkadang anak kurang menyukai dengan PMT yang diberikan karena kurang variasi, maka dari 9 ibu mengatakan yang mengkonsumsi makanan tambahan yang diberiakan diposyandu bukan anaknya saja melainkan anggota keluarga juga ikut mengkonsumsinya seperti ibu dan saudara kandung dirumah.

\section{BAHAN DAN METODE}

Jenis penelitian yang
digunakan
adalah quassy eksperiment dengan rancangan one group pretest dan posttest design dengan ini hasil perlakuan dapat diketahui lebih akurat karena membandingkan dengan keadaan sebelum diberikan perlakuan. Dalam desain penelitian ini, sampel akan diberikan pretest terlebih dahulu setelah itu diberikan perlakuan dalam hal ini yaitu pelatihan pembuatan PMT dengan menu lokal, dan setelah diberikan perlakuan sampel akan diberikan posttest. 
Populasi pada penelitian ini adalah Ibu yang memiliki Balita Gizi Kurang di Desa Leyangan yaitu sebanyak 55 Balita dengan Gizi Kurang. Peneliti melakukan pengambilan sampel secara proportuionate random sampling dengan cara mengambil 20 ibu yang memiliki balita dengan gizi kurang usia 12-59 bulan. Dalam penelitian ini instrument yang digunakan adalah lembar kuesioner dengan varibel pengetahuan berisikan 10 pertanyaan dan variable sikap sebanyak 12 pertanyaan. Kuesioner ini diisi oleh responden dengan variable pengetahuan pada kategori Baik, $\geq 76-100 \%$, Cukup 56$75 \%$,Kurang $\leq 55 \%$ (Wawan dan Dewi, 2011) dan pada variable sikap di kategorikan Positif jika $\mathrm{T} \geq$ mean yaitu 35,7, Negatif jika skor $\mathrm{T}<$ mean yaitu 35,7 (Azwar,2015).

Peneliti memberikan perlakuan pada $20 \mathrm{ibu}$ yang memiliki balita gizi kurang yaitu dengan memberikan pelatihan pembuatan PMT menu lokal yaitu Bola tempe Saus kuning dengan metode demonstrasi. Setelah diberikan intervensi responden diberikan lembar kuesioner untuk mengetahui adanya perbedaan sebelum dan sesudah diberikan pelatihan pembuatan PMT menu lokal.

Analisis data uji normalitas data menggunakan uji Shopiro-wilk. Uji ini bertujuan untuk mengetahui apakah distribusi data mempunyai distribusi normal atau tidak secara analitis, dengan menggunakan sampel sedikit atau kecil kurang dari 50 atau sama dengan 50 menggunakan uji Shapiro-Wilk (Dahlan, 2009), untuk menguji beda dua hasil pengukuran pada kelompok yang sama (missal beda pre test dan post test), analisis ini menggunakan Wilcoxon test (data tidak berdistribusi normal) dan menggunakan skala ordinal.

\section{HASIL}

Dari hasil penelitian didapatkan tingkat pengetahuan sesudah diberikan pelatihan PMT menu lokal pada kategori baik sebanyak 18 responden $(90,0 \%)$, kategori cukup sebanyak 2 responden $(10,0 \%)$. Pada sikap responden sesudah diberikan pelatihan PMT menu lokal sikap ibu dengan kategori positif sebanyak 19 responden $(95,0 \%)$ dan kategori sikap negatif sebanyak 1 responden $(5,0 \%)$.

Tabel 1. Distribusi Frekuensi Pendidikan Terakhir Responden

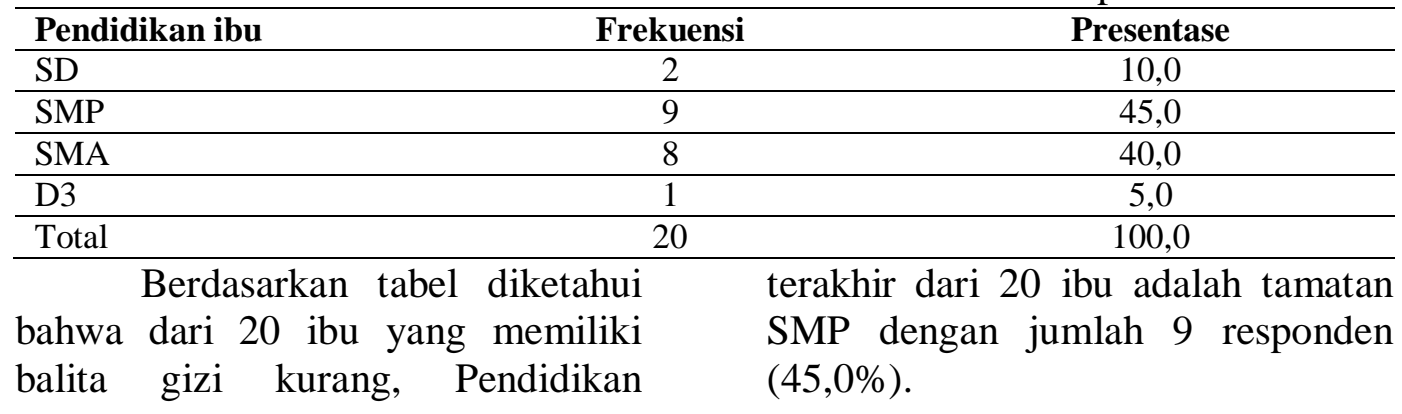

Tabel 2. Distribusi Frekuensi Pekerjaan Responden

\begin{tabular}{lcc}
\hline Pekerjaan & Frekuensi & Presentase \\
\hline IRT & 5 & 25,0 \\
\hline Buruh Pabrik & 6 & 30,0 \\
\hline Karyawan Swasta/Wiraswasta & 9 & 45,0 \\
\hline
\end{tabular}




\begin{tabular}{llll}
\hline Total & 20 & \multicolumn{2}{c}{100,0} \\
\hline Berdasarkan tabel 2 diketahui & memiliki balita gizi kurang yaitu \\
bahwa dari 20 ibu yang memiliki & bekerja sebagai & karyawan \\
balita gizi kurang, sebagian besar & swasta/wiraswasta & sebanyak 9 \\
dari 20 ibu di Desa Leyangan yang & responden $(45 \%)$. &
\end{tabular}

Tabel 3. Distribusi Frekuensi Pengetahuan Berdasarkan Responden Sebelum dilakukan Pelatihan Pembuatan PMT Menu Lokal di Desa Leyangan

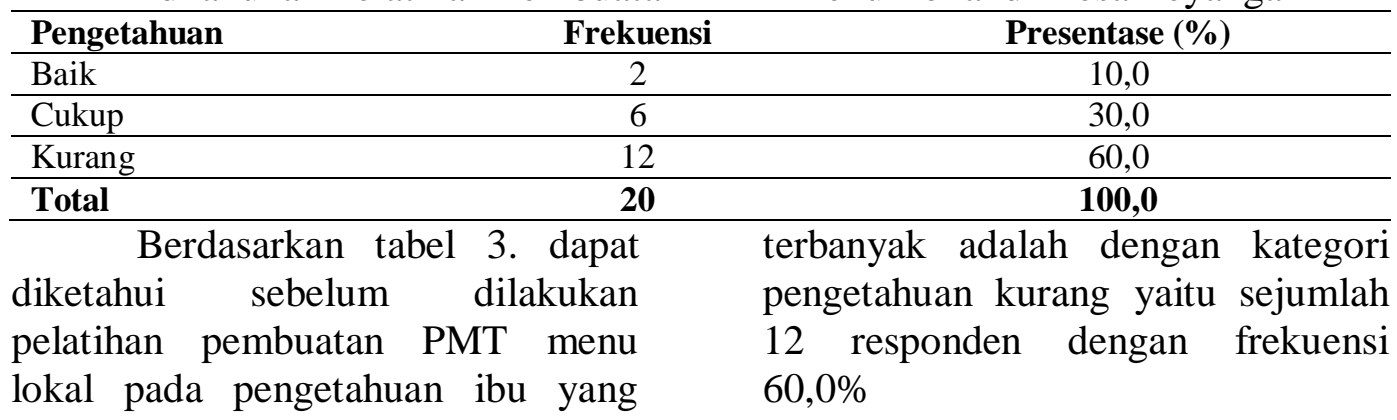

memiliki balita gizi kurang yang

Tabel 4. Distribusi Frekuensi Berdasarkan Pengetahuan ibu yang memiliki balita gizi kurang sesudah dilakukan Pelatihan Pembuatan PMT Menu Lokal di Desa Leyangan

\begin{tabular}{lclc}
\hline Pengetahuan & Frekuensi & Presentase (\%) \\
\hline Baik & 18 & 90,0 \\
\hline Cukup & 2 & & 0,0 \\
\hline Kurang & 0 & & 0 \\
\hline Total & 20 & $\mathbf{1 0 0 , 0}$ \\
\hline \multicolumn{2}{c}{ Berdasarkan tabel 4 dapat } & yang tertinggi adalah dengan \\
diketahui & sesudah dilakukan & kategori pengetahuan baik yaitu \\
pelatihan pembuatan PMT menu & sejumlah 18 responden dengan \\
lokal terhadap pengetahuan pada 20 & frekuensi 90,0\%.
\end{tabular}
ibu yang memiliki balita gizi kurang

Tabel 5. Distribusi Frekuensi Berdasarkan Sikap Responden Sebelum dilakukan Pelatihan Pembuatan PMT Menu Lokal di Desa Leyangan

\begin{tabular}{lcl}
\hline Sikap & Frekuensi & \multicolumn{1}{c}{ Presentase (\%) } \\
\hline Positif & 2 & 10,0 \\
\hline Negatif & 18 & 90,0 \\
\hline Total & 20 & 100,0 \\
\hline \multicolumn{2}{c}{ Berdasarkan tabel 5 . dapat } & balita gizi kurang yang tertinggi \\
diketahui & sesudah dilakukan & adalah dengan kategori sikap yang \\
pelatihan pembuatan PMT menu & negatif yaitu sejumlah 18 responden \\
lokal pada sikap ibu yang memiliki & dengan frekuensi 90,0\%.
\end{tabular}

Tabel 6. Distribusi Frekuensi Berdasarkan Sikap Responden Sesudah dilakukan Pelatihan Pembuatan PMT Menu Lokal di Desa Leyangan

\begin{tabular}{lcc}
\hline Sikap & Frekuensi & Presentase (\%) \\
\hline Positif & 17 & 85,0 \\
\hline Negatif & 3 & 15,0 \\
\hline Total & 20 & 100,0 \\
\hline
\end{tabular}


Berdasarkan tabel 6. dapat diketahui sesudah dilakukan pelatihan pembuatan PMT menu lokal pada sikap ibu yang memiliki

Tabel 7. Efektivitas pelatihan pembuatan PMT menu lokal terhadap Pengetahuan dan Sikap Responden Sebelum dan Sesudah Pelatihan Pembuatan PMT Menu lokal di Desa Leyangan

\begin{tabular}{cccccc}
\hline Variabel & Kelompok & $\mathbf{N}$ & $\mathbf{Z}$ & Mean & p-value \\
\hline Pengetahuan & Sebelum & 20 & $-3,932$ & 47,00 & 0,000 \\
\hline \multicolumn{5}{c}{ Post Test - Pre Test } \\
\hline \multicolumn{7}{c}{ Sesudah } & 20 & 88,50 \\
\hline Sikap & Asymp.Sign. (2-Tailed) & $0,000(p$-Value $)$ \\
\hline \multicolumn{7}{c}{20} & $-3,926$ & 31,35 & 0,000 \\
\hline & Sebelum & 20 & 40,05 \\
\end{tabular}

balita gizi kurang yang tertinggi adalah dengan kategori sikap yang positif yaitu sejumlah 17 responden dengan frekuensi $85,0 \%$.

\begin{tabular}{l} 
Data pada tabel 7 . diatas \\
\hline \multicolumn{3}{c}{ Psymp.Sign. $(2-T$} \\
dapat diketahui nilai signifikansi \\
pada variable pengetahuan sebesar \\
0,000 dan pada variabel sikap \\
sebesar $0,000 \quad(<0,005)$ artinya \\
terdapat skor yang signifikan \\
terhadap perlakuan sebelum dan \\
sesudah pelatihan pembuatan PMT \\
menu lokal atau dengan artian bahwa \\
ada perbedaan seblum dan sesudah \\
pelatihan pembuatan PMT menu \\
lokal terhadap pengetahuan dan sikap \\
ibu dalam memberikan PMT pada \\
balita dengan gizi kurang di Desa \\
Leyangan.
\end{tabular}

\section{PEMBAHASAN}

1. Gambaran pengetahuan ibu dalam memberikan PMT menu lokal pada balit a gizi kurang sebelum diberikan pelatihan pembuatan PMT menu lokal di Desa Leyangan.

Berdasarkan

hasil

penelitian dapat diketahui sebelum dilakukan pelatihan pembuatan PMT menu lokal terhadap pengetahuan pada 20 ibu yang memiliki balita gizi kurang yang tertinggi adalah dengan kategori pengetahuan baik yaitu hanya sejumlah 2 responden dengan presentase

$10,0 \%$, berpengetahuan cukup
yaitu 6 responden dengan
presentase $30,0 \%$ dan yang
tertinggi adalah berpengetahuan
kurang yaitu 12 responden
$(60,0 \%)$.

Hasil

penelitian didapatkan pendidikan ibu sebagian besar pada kategori menengah pertama sebanyak 9 responden $(45,0 \%)$. Tingkat pendidikan dan pengetahuan merupakan aspek yang berpengaruh terhadap usaha peningkatan gizi masyarakat, yang mencakup tingkat konsumsi keluarga. Kedua hal tersebut menentukan besar kecilnya penggunaan sebagian pendapatan keluarga dalam pengadaan makanan sehari-hari untuk dapat dikonsumsi oleh seluruh keluarga. Dalam penelitian ini, karakteristik keluarga meliputi tingkat pendidikan orang tua (ibu), tingkat pengetahuan ibu tentang pemberian makanan tambahan pada balita, pekerjaan orang tua,

Penelitian ini didukung oleh Suryani Linda, 2017 dengan judul penelitian faktor yang mempengaruhi status gizi balita 
di Wilayah Kerja Puskesmas Payung Sekaki Pekanbaru yang menyatakan bahwa, tingkat pendidikan dapat mempengaruhi pola pikir dan pengetahuan seseorang. Pendidikan merupakan suatu proses merubah pengetahuan, sikap, dan perilaku orang tua untuk mewujudkan status gizi balita yang baik. Pengaruh pendidikan dengan status gizi balita dengan nilai signifikan ( $p$-value 0,019). Pendidikan mempengaruhi status gizi balita karena semakin tinggi pendidikan seseorang ibu maka semakin baik pengetahuannya, semakin baik pengetahuan ibu terhadap gizi akan mempengaruhi cara ibu memberikan makanan kepada balitanya sehingga pemenuhan gizi balita akan terpenuhi.

Menurut Lestari (2015), menyatakan bahwa salah satu faktor yang mempengaruhi Pengetahuan adalah pendidikan dimana pengetahuan sanggat berhubungan dengan pendidikan, semakin tinggi pendidikan seseorang maka akan lebih banyak dan lebih luas pengetahuan orang tersebut.

2. Gambaran pengetahuan ibu dalam memberikan PMT menu lokal pada balita gizi kurang sesudah diberikan pelatihan pembuatan PMT menu lokal di Desa Leyangan.

Berdasarkan

hasil

penelitian dapat diketahui sesudah dilakukan pelatihan pembuatan PMT menu lokal terhadap pengetahuan pada 20 ibu yang memiliki balita gizi kurang yang tertinggi adalah dengan kategori pengetahuan baik yaitu sejumlah 18 responden dengan presentase $90,0 \%$ dan berpengetahuan cukup yaitu 2 responden dengan presentase $10,0 \%$.

Pengetahuan seseorang dipengaruhi oleh beberapa faktor yaitu diantaranya pengetahuan sangat berhubungan dengan pendidikan, semakin tinggi pendidikan seseorang maka akan lebih banyak dan lebih luas pengetahuan orang tersebut, Informasi didapat pada kehidupan sehari-hari, kemudian lingkungan dimana seseorang dapat mempelajari hal-hal baik juga buruk tergantung pada sifat kelompoknya, budaya yang memegang peran penting dalam pengetahuan, pendidikan merupakan hal yang mendasar untuk mengembangkan pengetahuan dan pengalaman yang merupakan guru terbaik dalam mengasah pengetahuan, status ekonomi dimana seseorang mampu memenuhi fasilitas yang dibutuhkan untuk memperoleh pengetahuan yang di inginkan dan usia mempengaruhi daya ingat dan daya tanggap seseorang, semakin berambahnya usia maka semakin banyak yang ditangkap dan dipelajari sehingga pengetahuan yang diperoleh semakin banyak dan semakin baik (Lestari, 2015).

Hasil penelitian ini didukung oleh penelitian Rante B (2014), dengan judul Studi pengetahuan dan sikap ibu tentang gizi balita di Kotaraya Barat menunjukkan bahwa ibu yang memiliki pengetahuan baik 27 responden $(93,10 \%)$ dari 29 responden, karena ibu telah tahu serta memahami tentang pemberian gizi pada Balita. 
Selain itu hal ini juga dapat disebabkan oleh banyak sumber informasi yang didapatkan, misalnya televisi, radio dan sebagainya serta ibu juga rajin dalam mengikuti penyuluhan tentang gizi balita yang diberikan oleh petugas kesehatan, sehingga banyak informasi yang mereka dapatkan.

Menurut penelitian

Susilowati E, Himawati A, 2017 menyatakan bahwa ibu yang memiliki pengetahuan baik mayoritas memiliki ballita dengan satus gizi baik lebih banyak dibanding dengan ibu yang berpengetahuan kurang dengan nilai signifikansi $\mathrm{p}$-value 0,006 maka ada hubungan yang signifikan antara tingkat pengetahuan ibu tentang gizi balita dengan satus gizi balita. Tingkat pengetahuan ibu tentang gizi balita sangat mempengaruhi keadaan gizi balita karena ibu adalah seorang yang paling besar keterkaitanya terhadap anak. Pengetahuan yang dimiliki ibu menjadi kunci utama kebutuhan gizi balita terpenuhi. Pengetahuan bias didapat dari informasi berbagai media seperti $\mathrm{TV}$, radio atau surat kabar. Seperti informasi yang didapatkan dari penyuluhan yang diberikan oleh program puskesmas setiap pelaksanaan program posyandu, informasi ini akan meningkatkan pengetahuan yang diiringi dengan perilaku baru dalam pemberian makanan bergizi bagi balita sehingga gizi pun menjadi baik.

Hal ini sejalan dengan pendapat Notoatmodjo (2012), mengemukakan bahwa pengetahuan merupakan hasil tahu dan terjadi setelah seseorang melakukan penginderaan terhadap suatu objek tertentu. Penginderaan terjadi melalui panca indera manusia yakni penglihatan, pendengaran, penciuman, rasa, dan raba. Pengetahuan dapat diperoleh antara lain melalui pendidikan baik kurikuler, nonkurikuler dan ekstrakurikuler. Pengetahuan juga dapat diperoleh dari pengetahuan orang lain diantaranya dengan mendengar, melihat langsung dan melalui alat komunikasi seperti televisi, radio, buku, dan lain-lain dapat meningkatkan pengetahuan seseorang.

Metode pelatihan dengan demonstrasi dan praktik memberikan keefektivitasan yang bermakna terhadap peningkatan pengetahuan. Pelatihan dengan metode ini memberikan kesan yang mendalam pada responden. Respoden melihat secara langsung pembuatan PMT. Hal ini sejalan dengan penelitian yang dilakukan oleh (Katmawanti dkk, 2018) menyimpulkan bahwa, ada peningkatan pengetahuan sesudah diadakan pelatihan dengan presentase sebelum $14,12 \%$ dan sesudah $71,00 \%$ peningkaatan sebesar $56,88 \%$. Hasil penelitian ini didukung juga oleh penelitian Marfuah D, Kurniawan I (2017), dengan judul upaya peningkatan pengetahuan ibu tentang MP-ASI dengan edukasi gizi menunjukkan hasil bahwa pada setelah diberikan edukasi gizi dapat meningkatkan pengetahuan secara signifikan $(p=0,022)$. Maka artinya ada efektivitas 
setelah diberikan edukasi gizi terhadap peningkatan pengetahuan ibu.

3. Gambaran sikap ibu dalam memberikan PMT menu lokal pada balita gizi kurang sebelum diberikan pelatihan pembuatan PMT menu lokal di Desa Leyangan.

Berdasarkan penelitian sebelum dilakukan pelatihan pembuatan PMT menu lokal terhadap sikap pada $20 \mathrm{ibu}$ yang memiliki balita gizi kurang yang tertinggi dengan ibu yang bersikap positif adalah hanya 2 responden $(10,0 \%)$ dan ibu yang bersikap negatif 18 responden (90,0\%).

Faktor-faktor yang mempengaruhi sikap adalah pengalaman Pribadi biasanya dapat menjadi dasar pembentukan sikap, pengalaman pribadi haruslah meninggalkan kesan yang kuat, pengaruh orang lain yang dianggap penting, individu cenderung untuk memiliki sikap yang konformis atau searah dengan sikap orang yang dianggap penting, pengaruh kebudayaan, tanpa disadari kebudayaan telah menanamkan garis pengaruh sikap kita terhadap berbagai masalah (Azwar, 2015).

Hasil penelitian ini didukung oleh penelitian Setyaningsih SR, Agustin N (2014) dengan judul pengetahuan sikap ibu dalam pemenuhan gizi balita menyebutkan bahwa, status gizi anak yang baik di latar belakangi oleh sikap ibu dalam pemenuhan gizi anak dimana sikap ibu kurang $60(57,1 \%)$ dari 112 responden, ada pengaruh yang signifikan antara sikap ibu dengan status gizi balita. Ibu yang memiliki sikap kurang baik berkemungkinan memiliki balita dengan status gizi kurang lebih besar daripada ibu yang memiliki sikap baik.

Terbentuknya sikap dapat dilakukan dengan memberikan pendidikan kesehatan atau pelatihan kesehatan. Tujuan Pelatihan mengembangkan keahlian, sehingga pekerjaan dapat diselesaikan dengan lebih efektif, mengembangkan pengetahuan, sehingga pekerjaan dapat diselesaikan secara rasional dan mengembangkan sikap, sehingga dapat menimbulkan kemauan untuk bekerjasama (Supariasa, 2016 ).

Hal diatas sejalan dengan penelitian yang dilakukan oleh Iftika N, Pratiwi E (2016), melakukan penelitian dengan judul pengaruh pendidikan kesehatan tentang status gizi balita terhadap pengetahuan, sikap dan perilaku ibu dalam memberikan gizi balita di kelompok bermain sendangadi, Melati Sleman Yogyakarta, Dalam penelitian ini didapatkan hasil bahwa sikap yang ada pada masyarakat mayoritas baik, hal ini tidak lepas dari pengetahuan yang dimilikinya, maka semakin baik sikap yang dijalani, dengan sikap yang baik bisa memenuhi status gizi.

Berdasarkan hasil penelitian didapatkan bahwa dari 20 ibu yang memiliki balita gizi kurang di Desa Leyangan pekerjaan ibu yaitu karyawan swasta sebanyak 9 responden (45\%), buruh pabrik sebanyak 6 responden $(30 \%)$ dan IRT sebanyak 5 responden (25\%). 
Hal ini didukung oleh penelitian Oktarina Mika, 2017 dengan judul penelitian hubungan sikap ibu dengan status gizi balita di Wilayah Kerja Puskesmas Sawah Lebar Kota Bengkulu yang menyatakan bahwa, ibu yang memiliki sikap negatif cenderung berperilaku slaah dalam memberikan makanan kepada balitanya. Satus gizi ballita kurang juga dapat disebabkan oleh pekerjaan ibu yang sangat menyita waktu sehingga makanan yang dikonsumsi anaknya tidak terkontrol. Balita yang gizinya baik diakrenakan sikap ibu yang positif dan baik dalam meningkatkan status gizi balitanya dalam hal mnegatur kebutuhan makanan serta menjaga kondisi anak agar senantiasa sehat. Dimana pada penelitian ini dengan nilai signifikansinya yaitu p-value 0,000 artinya terdapat hubungan antara sikap ibu dengan status gizi balita.

4. Gambaran sikap ibu dalam memberikan PMT menu lokal pada balita gizi kurang sesudah diberikan pelatihan pembuatan PMT menu lokal di Desa Leyangan.

Berdasarkan hasil penelitian dapat diketahui sesudah dilakukan pelatihan pembuatan PMT menu lokal terhadap sikap pada 20 ibu yang memiliki balita gizi kurang yang tertinggi dengan ibu yang bersikap positif adalah sebanyak 19 responden $(95,0 \%)$ dan ibu yang bersikap negatif hanya 1 responden $(5,0 \%)$.

Menurut Edwards dalam Azwar (2015), menyatakan bahwa sikap adalah suatu bentuk evaluasi atau reaksi perasaan. Sikap seseorang terhadap suatu obyek adalah perasaan mendukung atau memihak (favorable) maupun perasaan tidak mendukung atau tidak memihak (unfavorable) pada objek tersebut.

Sikap adalah reaksi atau respon seseorang yang masih tertutup terhadap suatu stimulus atau objek. Sikap juga merupakan suatu kesiapan atau kesediaan untuk bertindak, sikap belum dikatakan suatu tindakan atau aktivitas. Sikap merupakan hasil dari proses belajar seseorang yang tidak dibawa sejak lahir. Pembentukannya terjadi sepanjang hidup seseorang melalui interaksi dengan objek diluar dirinya, seperti kelompok, budaya dan sebagainya (Mubarok, 2012).

Penelitian ini didukung oleh penelitian Rante B (2014), yang menyatakan bahwa sebagian besar sikap ibu yang positif dalam pemberian gizi pada balita, disebabkan karena ibu sudah mampu mengatur cara pemberian makanan, cara mengolah makanan tambahan, sehingga kebutuhan gizi balita dapat dipenuhi. dan ibu yang bersikap kurang baik disebabkan karena sebagian besar karena ibu bekerja, sehingga mereka tidak sempat membawa balitanya ke Posyandu untuk melakukan pemeriksaan rutin setiap bulan dan ibu juga kurang mendapatkan informasi penyuluhan yang disampaikan oleh tenaga kesehatan.

5. Efektivitas Pelatihan Pembuatan PMT Menu Lokal 
Terhadap Pengetahuan dan Sikap Ibu dalam Memberikan PMT pada Balita dengan Gizi Kurang

\begin{tabular}{lrr}
\multicolumn{2}{c}{ Menurut } & Supariasa \\
(2016), menyatakan & bahwa \\
pelatihan & adalah & bagian \\
pendidikan & yang menyangkut \\
proses & belajar & untuk
\end{tabular} memperoleh dan meningkatkan keterampilan diluar sistem pendidikan yang berlaku, dalam waktu yang relatif singkat dan dengan menggunakan metode yang lebih mengutamakan praktik dari pada teori. Pelatihan pada hakikatnya merupakan upaya untuk menigkatkan kemampuan yang meliputi pengetahuan, sikap, dan keterampilan dalam melaksanakan tugas yang telah di tetapkan.

Makanan tambahan adalah makanan bergizi sebagai tambahan selain makanan utama bagi kelompok sasaran guna memenuhi kebutuhan gizi. Makanan lokal adalah bahan makanan atau makanan yang tersedia dan mudah diperoleh di wilayah setempat dengan harga terjangkau. Makanan pabrikan adalah makanan jadi hasil olahan pabrik (Kemenkes RI, 2011).

Pada hasil penelitian dijelaskan bahwa $\mathrm{N}$ positif sebesar 20 dengan nilai rata-rata 10,50 terdapat peningkatan pengetahuan terhadap 20 responden pada nilai jawaban sebelum dan sesudah diberikan pelatihan pembuatan PMT menu lokal.

Pengetahuan seseorang dipengaruhi oleh beberapa faktor yaitu diantaranya pengetahuan sanggat berhubungan dengan pendidikan, semakin tinggi pendidikan seseorang maka akan lebih banyak dan lebih luas pengetahuan orang tersebut, Informasi didapat pada kehidupan sehari-hari, kemudian lingkungan dimana seseorang dapat memplajari hal-hal baik juga buruk tergantung pada sifat kelompoknya, budaya yang memegang peran penting dalam pengetahuan, pendidikan merupakan hal yang mendasar untuk mengembangkan pengetahuan dan pengalaman yang merupakan guru terbaik dalam mengasah pengetahuan, status ekonomi dimana seseorang mampu memenuhi fasilitas yang dibutuhkan untuk memperoleh pengetahuan yang di inginkan dan usia mempengaruhi daya ingat dan daya tanggap seseorang, semakin berambahnya usia maka semakin banyak yang ditangkap dan dipelajari sehingga pengetahuan yang diperoleh semakin banyak dan semakin baik (Lestari, 2015).

Menurut penelitian Menurut penelitian Setyaningsih SR, Agustin N (2014), menyatakan bahwa responden memiliki pengetahuan baik tertinggi cenderung memilih makanan, sedangkan yang memiliki pengetahuan kurang tertinggi pada terdapat masalah dalam pemilihan makanan dan gizi anak. Peneliti berasumsi pengetahuan ibu yang baik dalam hal memilih makanan salah satunya karena perkembangan media massa baik elektronik dan cetak. Hal tersebut mempermudah ibu mendapatkan informasi mengenai cara memilih 
sayuran, buah, daging, ataupun ikan yang baik untuk anak. Masalah makan dan gizi anak, masih banyak didapatkan pada ibu yang memiliki pengetahuan kurang baik dikarenakan terbatasnya pengetahuan ibu mengenai istilah masalah gizi pada anak contohnya seperti istilah KEP (kurang energi protein). Berdasarkan hasil analisis terlihat bahwa responden dengan pengetahuan yang baik, status gizi balitanya juga baik, ibu yang memiliki pengetahuan baik, memiliki anak dengan status gizi yang baik pula.

Metode demostrasi adalah mengajarkan secara nyata bagaimana melakukan atau menggunakan sesuatu, dan menunjukan cara-cara atau prosedur dengan teknik-teknik yang baru (Fratidhina dan Syafrudin, 2013).

Penelitian ini didukung oleh Susanti Y, Devi M, Katmawanti M ( 2017), yang menyatakan bahwa metode pelatihan dengan demonstrasi dan praktik memberikan keefektivitasan yang bermakna terhadap peningkatan pengetahuan. Pelatihan dengan metode ini memberikan kesan yang mendalam pada responden. Respoden melihat cara melakukan pembuatan PMT. Terdapat keefektivitasan pelatihan terhadap pengetahuan Ibu terkait PMT modisco di Kelurahan Tanjungrejo Kecamatan Sukun Kota Malang. Peningkatan pengetahuan Ibu mengenai PMT Modisco meningkat setelah diadakan pelatihan, diketahui bahwa nilai Sig. (2-tailed) sebesar $0,000<$
0,05 artinya terdapat keefektivitasan pelatihan terhadap pengetahuan Ibu terkait PMT modisco.

Penelitian didukung oleh penelitian Irianti (2016), mengatakan bahwa pengetahuan ibu sangat mempengaruhi pada pertumbuhan balita. Pengetahuan ibu yang rendah mengakibatkan pertumbuhan balita tidak baik dan mengakibatkan kekurangan gizi. Ibu kurang mendapatkan informasi mengenai bagaimana cara memilih bahan makanan yang tepat untuk balita, bagaimana memasak yang baik dan benar, serta bagaimana cara memilih menu makanan yang baik untuk keluarga untuk itu ibu sebaiknya mencari informasi baik dari buku ataupun tenaga kesehatan, dimana hasil penelitian di dapatkan sebagian tingkat pendidikan yang rendah ini mempengaruhi tingkat pengetahuan dan penghasilan orang tua balita.

Jadi dapat peneliti simpulkan bahwa pendidikan sangat mempengaruhi pengetahuan yang dimiliki seseorang, maka pendidikan yang tinggi dapat mempengaruhi pengetahuan seseorang untuk menanigkatkan informasi yang diperoleh dan pengetahuan dapat diperoleh melalui informasi yang disaring dari sebuah pengalaman, melihat, mengevaluasi, dan bukan hanya sekedar teori yang didapat namun teori tersebut dapat dipraktikkan. Maka informasi yang didapat akan lebih mudah di ingat Pada penelitian dijelaskan bahwa $\mathrm{N}$ positif sebesar 20 dengan nilai rata-rata 
10,50, terdapat perubahan sikap responden yang memiliki balita gizi kurang menjadi sikap positif pada 20 responden sebelum dan sesudah diberikan pelatihan pembuatan PMT menu lokal, 0 responden dengan sikap negatif atau tidak mengalami perubahan baik sebelum dan sesudah diberikan pelatihan pembuatan PMT menu lokal.

Menurut

Menurut

Purwanto dalam Wawan dan Dewi (2014), menyatakan bahwa sikap positif kecenderungan mendekati, menyenangi, mengharapkan suatu objek. Sikap negatif kecenderungan untuk menjauhi, menghindari, dan tidak menyukai objek tertentu.

Pada hasil penelitian bahwa jika sikap ibu positif mau memberikan makanan tambahan kepada balita maka status gizi balita akan berpengaruh baik. Maka pelatihan pembuatan PMT menu lokal efektif untuk merubah ibu ke sikap yang positif secara signifikan $(\mathrm{p}=0,000)$ untuk memberikan makanan tambahan menu lokal untuk meningkatkan status gizi balita yang baik.

Penelitian ini didukung oleh penelitian Rante B (2014),

\section{KEPUSTAKAAN}

Azwar, Saifuddin (2015). Sikap Manusia Teori dan

Pengukurannya. Yogyakarta: Pustaka Pelajar.

Dahlan, M.S (2009). Statistik untuk Kedokteran dan Kesehatan. Jakarta: Salemba Medika: https:// books.google.co.id/books?id= Abh5oa3QIMC\&pg= yang menyatakan bahwa sebagian besar sikap ibu yang poitif dalam pemberian gizi pada balita, disebabkan karena ibu sudah mampu mengatur cara pemberian makanan, cara mengolah makanan tambahan, sehingga kebutuhan gizi balita dapat dipenuhi. dan ibu yang bersikap kurang baik disebabkan karena sebagian besar karena ibu bekerja, sehingga mereka tidak sempat membawa balitanya ke Posyandu untuk melakukan pemeriksaan rutin setiap bulan dan ibu juga kurang mendapatkan informasi penyuluhan yang disampaikan oleh tenaga kesehatan.

Maka dapat disimpulkan peneliti bahwa pelatihan pembuatan PMT menu lokal efektif digunakan untuk meningkatkan pengetahuan dan sikap ibu dalam memberikan PMT pada balita dengan gizi kurang di Desa Leyangan dapat diartikan bahwa $\mathrm{H}_{(\mathrm{A})}$ diterima dan $\mathrm{H}_{(0)}$ yaitu tidak ada efektivitas sebelum dan sesudah pelatihan pembuatan PMT menu lokal pada balita dnegan gizi kurang di Desa Leyangan atau diartikan di tolak.

$$
\begin{aligned}
& \text { PA53\&dq }=\text { metode }+ \text { Shapiro }+ \\
& \text { Wilk\&dl=ban \&sa=X\&ved=Oa } \\
& \text { hUKEwjZnZDT- } \\
& \text { t3hAhVd4HMBccmA } \\
& \text { Faq6aeikJaB\#v=onepage } \\
& \& q=\text { metode } \% 20 \text { Shapiro } \% 20 \mathrm{~W} \\
& \text { ilk\&f=false. Diakses pada } \\
& \text { tanggal } 1 \text { Mei } 2019 .
\end{aligned}
$$

Hermiyanti, dkk (2017). Faktor Risiko Kejadian Gizi Kurang Pada 
Balita Usia 24-59 bulan di Kelurahan Taipa Kota Palu. Medika Tadulako: Jurnal Ilmiah Kedokteran, Vol. 7 No. 2. http://jurnal.untad.ac.id/jurnal /index.php/Preventif/article/view/833 8DOI:

http://dx.doi.org/10.22487/j25 283375.2016.v7.i2.8338

Iskandar. (2017). Pengaruh pemberian makanan tambahan modifikasi terhadap

status gizi balita. Jurnal AcTion: Politeknik Kesehatan Kemenkes Aceh. Vol 2 No.2: P-ISSN : 2527-3310 E-ISSN : 2548-5741.

http://ejournal.poltekkesaceh.a c.id/index.php/an/article/view/ 65.DOI:

http://dx.doi.org/10.30867/acti on.v2i2.65

Iftika N, Pratiwi E (2016). Pengaruh Pendidikan Kesehatan Tentang Status Gizi Balita Terhadap Pengetahuan, Sikap Dan Perilaku Ibu Dalam Memberikan Gizi Balita Di Kelompok Bermain Sendangadi, Melati Sleman Yogyakarta: http://digilib.unisayogya.ac.id/ 2468/1/naskah\%20publikasi\% 20NUR\%20IFTIKA\%20PDF.p $d f$

Kemenkes RI (2017). Profil Kesehatan Indonesia Tahun 2017. Jakarta: Kementrian Kesehatan RI. 2018. http://www.kemenkes.go.id . diakses pada tanggal 30 April 2019.

Kapmawanti, Septa dkk (2018). Efektivitas Pelatihan Pembuatan PMT Modisco
Terhadap Pengetahuan Ibu di Kelurahan Tanjungrejo Kecamatan Sukun Kota Malang. Jurnal Preventia: Universitas Negeri Malang. Vol.3 No.1. ISSN:2528-3006: http://journal2.um.ac.id/index. php/preventia/article/view/387 5.

Lestari, Titik (2015). Kumpulan Teori Untuk Kajian Pustaka Penelitian

Kesehatan. Yogyakarta: Nuha Medika

Maisarah, FU. (2018). Hubungan status Pekerjaan Ibu, Tingkat Pendapatan

Keluarga, Tingkat Pengetahuan Ibu Tentang Gizi dan Pemberian ASI Eksklusif terhadap Status Gizi Balita. Skripsi: Universitas Muhamadiyah Surakarta.

Rante B. (2014). Studi Pengetahuan Dan Sikap Ibu Tentang Gizi Pada Balita Di Desa Kotaraya Barat. Jurnal Keperawatan Politeknik Kesehatan Kementerian Kesehatan Palu: Vol. 18 No. 1.

http://jurnal.untad.ac.id/jurnal/ index.php/Kreatif/article/view/ 4327

Wawan A dan M. Dewi (2014). Teori dan Pengukuran Pengetahuan, Sikap dan Perilaku Manusia.Yogyakarta: Nuha Medika.

Supriasa, I Dewa, Nyoman (2016). Pendidikan dan Konsultasi Gizi. Jakarta: EGC. 
Suryani Linda, (2017). Faktor yang Mempengaruhi Status Gizi Balita di Wilayah

Kerja Puskesmas Payung

Sekaki Pekanbaru. Jurnal of

Midwifery Sciences: Vol 1

No.2 P-ISSN.2549-2543,E-

ISSN: 2579-7077.

http://webcache.googleusercon

tent.com/search? $q=$ cache $: T V z v$

AY892uIJ:jurnal.univrab.ac.id/

index.php/jomis/article/downlo

$a d / 198 / 133+\& c d=1 \& h l=i d \& c t$

$=c \ln k \& g l=i d \& c l i e n t=$ firefox -

$b-d$.

Susilo E, Hirmawati A, (2017).

Hubungan Tingkat Pengetahuan Tentang Gizi

Balita dengan Status Gizi Balita di Wilayah Kerja Puskesmas Gajah 1 Demak. Jurnal Kebidanan: Vol.6 No.13: $\quad$ ISSN.2089-7669. http://ejournal.poltekkesmg.ac. id/ojs/index.php/jurkeb/article/ view/2866.DOI:http://dx.doi.org/ 10.31983/jkb.v6i13.2866.

Notoatmodjo, S. (2012). Metodologi Penelitian Kesehatan (2 ed.). Jakarta: Rineka Medika.

Marfuah D, Kurniawan I. (2017). Upaya Peningkatan Pengetahuan Ibu tentang MP Asi dengan Edukasi Gizi Melalui Booklet. Stikes

PKU Muhammadiyah Surakarta: journal.ummgl.ac.id/index.ph $\mathrm{p} /$ urecol/article/download/1195/81

Iftika N, Pratiwi E (2016). Pengaruh Pendidikan Kesehatan Tentang Status Gizi Balita Terhadap Pengetahuan, Sikap Dan Perilaku Ibu Dalam Memberikan Gizi Balita Di
Kelompok Bermain

Sendangadi, Melati Sleman Yogyakarta:

http://digilib.unisayogya.ac.id/ 2468/1/naskah\%20publikasi\% 20NUR\%20IFTIKA\%20PDF.p $d f$

Oktarina, Mika, (2017). Hubungan Sikap Ibu dengan Status Gizi Balita di Wilayah Kerja Puskesmas Sawah Lebar Kota Bengkulu. Jurnal Medika Respati: Vol 12 Nomor 4: ISSN.1907-3887. http://medika.respati.ac.id/ind ex.php/Medika/article/view/85

DOI:

https://doi.org/10.35842/mr.v $12 \mathrm{i} 4.85$

Mubarok. (2012). Pengetahuan Sikap Dan Perilaku Kesehatan Masyarakat. Nuha Medika: Yogyakarta

Fratidhina Y dan Syafrudin (2013). Promosi Kesehatan Untuk Mahasiswa

Kebidanan. Jakarta: CV Trans Info Media.

Irianti, Berliana (2016). Faktorfaktor yang Menyebabkan status Gizi kurang Pada Balita di wilayah Kerja Puskesmas Sail Pekanbaru Tahun 2016. Pekanbaru: Akademi Kebidanan Internasional Pekanbaru: Midwifery Journal,Vol. 3 No. 2ISSN 2503-4340/e-ISSN 2614-3364. https://media.neliti.com/media/ publications/278709-faktorfaktor-yang-menyebabkanstatus-gi-fcec1625.pdf. 